\title{
UM RELÓGIO NA SALA: TEMPO, ALEGORIA E HISTÓRIA EM AVALOVARA
}

\section{A CLOCK IN THE ROOM: TIME, ALLEGORY AND HISTORY IN AVALOVARA}

Pedro Couto*

RESUMO: Analisa-se o fragmento $\mathrm{P}$, “O Relógio de Julius Heckethorn", do romance Avalovara, de Osman Lins (1924 - 1978), publicado em 1973, a fim de enfocar o caráter alegórico que a publicado em 1973, a fim de enfocar o caráter alegórico que a
linha representa para a totalidade poética do romance. Ensaiamos demonstrar como, tematicamente, a página inicial do livro é uma espécie de pista cifrada, enfocando-se um objeto ali descrito, um relógio, que reverbera em outras instâncias textuais da trama de Osman Lins e representa uma alegoria da arte de escrever romances. Faz-se uma breve contextualização da história de relógios e noções científico-filośficas de tempo/temporalidade. (POMIAN, 1993). Também, valemo-nOs da discussoo sobre as . aporias do tempo e sua relação poetica. (RICOEUR, 1994; 2010). Por fim, argumentamos que o romance anuncia, inserido na poética osmaniana, uma resposta não soteriológica e não escatológica da História. O texto de Lins se apoia no tantra, no encontro não binarista dos corpos: o gozo, também tematicamente trabaIhado no romance, coloca o Amor como gravidade em torno da qual a Política se presentifica.

PALAVRAS-CHAVE: Osman Lins; Tempo; Temporalidade; Alegoria; História. couto.pedroh@gmail.com

Doutor em Literatura pela Universidade de Brasília. Professor do Instituto Federal de Brasília.

ABSTRACT: We analyze the fragment $P$, “O Relógio de Julius Heckethorn", from the novel Avalovara, published in 1973 by Osman Lins $(1924-1978$,$) to focus on the allegorical feature that$ the fragment has in the poetic totality of the novel. We try to demonstrate how the book's first page thematically works as an encrypted clue, focusing on an object described there, a clock, whose importance reverberates in other textual instances of Osman Lins' novel and also represents an allegory of the art of writing novels. A brief contextualization of the history of clocks and of the scientific-philosophical notions of time / temporality is pre(POMIAN, 1903) Also, we debate the aporetic notion of (ime (t) we and its poetic relation. (RICOEUR, 1994; 2010.) Furthermoe, we suggest that the novel announces, within the Osmanian poetics, a non-soteriological and non-eschatological response to History. Lins' text is based on tantra, in the non-binary encounter of bodies: pleasure, also thematically explored in the novel, places Love as gravity, around which Politics presents itself.

KEYWORDS: Osman Lins; Time; Temporality; Allegory; History. 


\section{NO ESPAÇO AINDA OBSCURO DE UM ROMANCE: O}

\section{INÍCIO DE AVALOVARA, DE OSMAN LINS}

Leiamos o primeiro parágrafo - a porta de entrada - de Avalovara:

No espaço ainda obscuro da sala, nesta espécie de limbo ou de hora noturna formada pelas cortinas grossas, vejo apenas o halo do rosto que as órbitas ardentes parecem iluminar - ou talvez os meus olhos: amo-a - e os reflexos da cabeleira forte, opulenta, ouro e aço. Um relógio na sala e o rumor dos veículos. Vem do Tempo ou dos móveis o vago odor empoeirado que flutua? Ela junto à porta, calada. Os aerólitos, apagados em sua peregrinação, brilham ao trespassarem o ar da Terra. Assim, aos poucos, perdemos, ela e eu, a opacidade. Emerge da sombra a sua fronte - clara, estreita e sombria. (LINS, 1995, p. 13) (grifo meu).

A sala esconde e prepara algo que o leitor ignora. Talvez seja a sala - seu espaço ainda obscuro - algo como o próprio romance que o leitor detém consigo. Os elementos se espraiam, refratados de algo maior, sob o qual se organizam. Um paradoxo reina nesta passagem inicial: coexistem, simulta nea mente, claridade e escuridão. Elementos contraditórios que, não permitindo-os a Lógica, autorizam-nos a Literatura. A escuridão é causada pelas cortinas grossas que amortecem a luz, ardente, que ema na não especificamente de uma lâmpada no recinto fechado, mas dos olhos de um homem e de uma mulher que se a mam. A claridade da cena, portanto, liga-se à visão e ao a mor. Impondo-se algum realismo à mesma passagem, o paradoxo é admitido (e reinterpretado) pela crença em uma espécie de penumbra que revolve o ambiente. Ainda assim, há elementos verbais curiosos que chama m atenção. Olhos e órbitas adquirem, no parágrafo, uma semântica ambígua, que singra do vocabulário a na tômico ao astronômico (o restante das palavras confirma a hipótese: halo, cabeleira - no caso, a analogia aos cabelos com os rastros dos cometas -, aerólitos). Passa-se do corpo físico, a na tômico ao corpo celeste. Há também a nomeação sugestiva de metais, que a crítica (HAZIN, 2013, p. 80) identificou - em parte devido à própria sugestão de Osman Lins: “Também Pitágoras e a alquimia não são estra nhos à minha atração pelas figuras geométricas" (LINS, 1979, p. 179) - como um motivo alquímico. Tal motivo esotérico ta mbém reforçado pela porta, alegoria da iniciação, do começo e da passagem, ao lado da qual está a amante. Neste fragmento inicial, apresenta o narrador na descrição da sala um único móvel: um relógio. A menção surge por coincidência ou pela necessidade da verossimilhança de se listar o mobiliá rio de um recinto fechado? É um relógio de que tipo? No próximo fragmento desta narração, passa-se a saber que 
é um relógio de caixa, alto, e, caso retirado o pêndulo, "poderiam esconder-se uma criança e seu cão na caixa de madeira do relógio.” (LINS, 1995, p. 14).

Por que um relógio é descrito, solitário, em meio à penumbra de uma sala?

Essa é uma pergunta fundamental em Avalovara. Antes de respondê-la, é preciso contextualizar o romance. Do que trata o livro? Grosso modo, é uma história de a mor: um homem enlaçado em três amores. Ao fim da estória, o tal homem é assassinado. Ele e ta mbém uma de suas a mantes. Saberá o leitor, após haver percorrido o livro, entre tantas outras coisas, que a sala descrita na página inicial faz parte de um apartamento na Avenida Angélica, em São Paulo, e funciona como preâmbulo para as ações que constituem a marcha do enredo, e para aonde desembocam. Não há nada de policial na trama. Se o há, certamente não foi a primeira opção de Osman Lins ao escrever seu romance que, segundo uma das cinco epígrafes (verdadeiras chaves interpretativas de Avalovara), a de Paul Zumthor, trata de aventuras e intrigas a morosas (a base de um grande filão da imaginação humana). O prefácio da obra, assinado por Antonio Candido, reforça essa leitura, cujo núcleo reside no tema a moroso e, ademais, explica a estrutura narrativa (em linhas temáticas) do livro:

As linhas são oito, e o seu desdobramento se traduz na história de um homem e das mulheres que a mou: uma na Europa, uma em Recife e sobretudo, uma em São Paulo, que de certo modo recebe a experiência a morosa vivida como nas anteriores. As duas primeiras seriam passado, mas funcionando como presente; a última é um presente que se forma a cada instante do passado. Toda a narrativa converge para plenitude amorosa numa espécie de gigantesca câmara lenta, que concentrasse o tempo no espaço limitado e no limitado instante em que a plenitude é buscada. (CANDIDO, 1995, p. 9).

O romance de Osman Lins, portanto converge para o a mor e tem o presente como régua. Os temas se disseminam e se entrecruzam a partir de uma concepção matemática e poética que se sustenta a partir de uma frase supostamente mágica "SATOR AREPO TENET OPERA $R O T A S$ ", formada por 8 letras e distribuída 25 vezes dentro de um quadrado perpassado por uma espiral. Aliás, a própria relação da espiral em relação às letras seria uma progressão aritmética que resulta ria nas linhas do romance. Dizia O. L. a Paulo Fernando Craveiro, em carta da tada de 4 de novembro de 1972. "Assim, é verdade que eu sei, desde o início, não apenas quantas páginas terá 
a obra: até a passagem final (que não será medida ou controlada), terei escrito, com pequena margem de erro, 13.650 linhas" (apud IGEL, 1988, p. 104.).

Se um crítico ignora este fato (Antonio Candido não o ignorou), certas qualidades do livro evadem. (A apresentação de Candido é ta mbém uma tentativa de elucidar o plano estruturante do romance). Para além da concepção de rigor matemático-poético, as epígrafes de Avalovara são inscrições temáticas eleitas por O.L. que orga nizam certos assuntos do romance. Elas se afinam numa espécie de mapa interpretativo que terá a rota escolhida pelo hermeneuta que lhe trace o itinerá rio. Justapõem-se ao tema do Amor (ZUMTHOR) outros motes: Tantra (MAXPOL FOUCHET), Cosmogonia (ELIADE), Palavra (GUSDORF) e Ordem (CURTIUS).

Em um protocolo de leitura que exige ao máximo a inteligência e sensibilidade do leitor, Osman Lins cifrou todos os temas de Avalovara já no introito, como numa tentativa de metonímia, pars pro toto. Os temas serão repetidos e enfatizados inúmeras vezes ao longo do livro. Qual será o propósito dessa obsessão? Uma primeira leitura de Avalovara, como lembra Elizabeth Hazin, não permite que se veja que a repetição de determinados elementos "termina por estabelecer profunda conexão entre eles, concedendo ao romance a imagem de um mundo completo e coeso, como desejava seu autor." (2014, p. 327). O aparentemente disperso e alea tório do texto osmaniano se revela, após sucessivas leituras, coerente, necessário e uno: união. O livro se constrói a partir de uma grande alegoria da própria escritura romanesca tapetes, peixes e pássaros, sons, eclipses, mapas revelam uma secreta ligação em que tais objetos/entes se inflam de um sopro alegórico, a fim de remeter, literariamente, à arte de escrever e a criação de mundos.

A união (ou unidade) que pretendo, através da presente leitura, (re)estabelecer neste ensaio, centra-se no relógio da cena inicial e, paralelamente, nas dimensões temporais que evoca. O relógio inventado por Osman Lins (entre outros que o romance lista) funciona como um elemento que representa a construção de Avalovara e ao mesmo tempo pode evocar a preocupação do tempo como categoria de narração do livro e situar, direta ou indiretamente, uma concepção histórica particular em que se pretendeu a rticular no livro, a da influência do tempo mítico sobre o tempo histórico. ${ }^{1}$

Em certo momento de Avalovara, uma personagem, na estação de Saint-Lazare, em Paris, nota a quantidade de relógios e indaga: "por que tantos relógios na estação?" 
(LINS, 1995, p. 260). A mesma pergunta serve para interrogar o motivo pelo qual esses objetos preenchem $\mathrm{ad}$ nauseam o romance de Osman Lins. O livro registra uma série de relógios, inventariados e elencados por diversos personagens em sua trama, como se fosse o romance de O.L. um museu dedicado a esse objeto. ${ }^{2}$

É sabido que os romancistas utilizam uma concepção específica de tempo em sua escrita, revelada por meio de uma técnica: o manejo do tempo, no romance, será realizado pela manutenção (ou ruptura) de uma tradição romanesca. Há sempre um modo peculiar em que o tempo se articula em um romance. Benedito Nunes menciona o surgimento do romance na História e Sociedade modernas e "não, por acaso, ta mbém aquela em que está começando a cronometria do trabalho e da produção, que levou o controle dos relógios mecânicos, depois que se tornaram mais precisos, a estender-se sobre toda a vida social." (NUNES, 2013, p. 48). Os relógios tiveram um impacto na própria arquitetura temporal (POMIAN 1993, p. 27). Saía-se do tempo litúrgico, do tempo cósmico, e instalava-se o tempo dos relógios. Não apenas um instrumento cuja utilidade era a de mensuração - o relógio revelava uma espécie de organização social:
(...) relógios hidráulicos, primeiro, que parecem ter sido muito procurados, e depois, a partir do século XIII, relógios mecâni$\cos ($....). Descendentes dos planetários, dos equatoriais e dos astrolábios, que permitiam aos astrónomos medir o tempo sideral e o verdadeiro tempo solar, os primeiros relógios, menos instrumentos de medida do tempo que visualização do modelo do universo [White 1962, trad. it. pp. 181-82; e para os astrolábios North 1974], imitavam, a princípio de modo muito imperfeito, o tempo uniforme da esfera celeste, que desse modo reportavam para a Terra. Sem que ninguém desse conta, os relógios lançavam uma primeira ponte sobre o abismo que se supunha dividir, segundo a teoria de Aristóteles, os fenómenos sublunares, sujeitos à geração e à corrupção, e a regularidade não-modificável do movimento das estrelas fixas. Mas antes que esta inovação produzisse efeitos no ca mpo científico, outro aspecto do relógio, o seu aspecto propria mente social e até político, depressa fez dele um instrumento público cujo funcionamento não concernia um pequeno grupo de estudiosos, mas todos os habitantes da cidade. Com efeito, a capacidade de mostrar o tempo, dando as horas, com o céu encoberto e com o céu limpo, de dia e de noite, levou no século XIV as cidades a instala rem relógios na torre sineira e no campanário da catedral, ao mesmo tempo que o rei de França colocava um no seu palácio [Le Goff 1960, trad. it. p. 14; Cipolla 1967, pp. 40 segs.]. (POMIAN, 1993, p. 27). 
De Balzac, no século XIX, em cujos romances, nos recuos e prospecções, ainda reinava o tempo dos relógios (ZÉRAFFA, 1971, p. 22), chega-se a Proust, que conquistou "a abertura da narrativa romanesca ao tempo vivido, à duração interior”. (NUNES, 2013, p. 49).

Voltemos à pergunta referida anteriormente para saber, especificamente, qual o tempo (ou temporalidade) que Osman Lins problematizou em seu romance. O porquê de o relógio da cena inicial ser tão representativo é nosso ponto de partida.

\section{“À PRIMEIRA VISTA, NADA, NESSA MÁQUINA DESPERTA ATENÇÃO”: O RELÓGIO DE JULIUS \\ HECKETHORN}

A linha P, uma das oito em Avalovara, fala de um relógio de caixa, de madeira, e é composta por dez fragmentos. Sua história, específica, possui uma estranha autonomia em relação ao restante do romance, uma vez que não se centra no protagonista da intriga nem em suas a mantes. Há uma espécie de viagem, espacial e temporal, que situa o relógio desde sua criação, por um músico e mecânico, e episódios sincronizados ao longo do século XX passando pelas duas guerras mundiais, que influem em seu paradeiro. Podería mos quase arriscar dizer que o relógio é o personagem sobre o qual a linha se desenvolve, embora receba o nome de seu inventor: Julius Heckethorn. Já se disse que "o tempo é um dos grandes protagonistas de Avalovara - o tempo em sua mais variadas possibilidades, em suas mais remotas implicações”. (DALCASTAGNÈ, 2000, p. 109).

O relógio de que se ocupa o narrador "e do qual não existe, que se saiba, réplica no mundo” (LINS, 1995, p. 211) virá das mãos e oficina de um homem chamado Julius Heckethorn, "esse artista gentil e um pouco assustado, que fala com igual entusiasmo de Mozart e de Silvestre II, papa, relojoeiro e entendedor de mecânica celeste" (LINS, 1995, p. 273), alemão de ascendência inglesa. O relógio sobreviverá, entre episódios va riados, ao nazismo, será esquecido em um porão e, acabará vindo de navio ao Brasil e, espólio da fortuna de um diplomata, será enfim leiloado. Eventualmente (as circunstâncias exatas da aparição do relógio no apartamento onde ocorre o assassínio são vagas) integra a residência decadente da Avenida Angélica. A ele mesclam-se histórias de pessoas: seu criador, a família, e seus possuidores. A ele mescla-se a história de países. Várias histórias convergem também numa interpretação da História novecentista. E à narrativa do próprio relógio somar-se-ão vidas humanas, os episódios que rodeiam uma trajetória singular: traição, trabalho, falência, agitação política, enfermidade, 
suicídio. Um objeto em meio a diversas vidas e segredos que integram o livro que o leitor lê.

O fragmento inicial da linha P evoca um sentido cosmológico. Para Osman Lins, o cosmológico, natural, torna-se, pela criação humana, artístico. A luz do Sol se revela uma flor, geométrica, fabricada pela engenhosidade humana. Este é o insight a respeito do relógio solar de Anaximandro de Mileto que traduz a obsessão osmaniana sobre a alegorização do fazer literário. O narrador, no fragmento de número um, ressalta a intimidade dos relógios com o mundo e as estrelas, que espelham: opõem o transitório ao eterno. Os relógios tentam imprimir ritmo, através de uma tradução numérica, da "marcha solene e delicada dos astros”. (LINS, 1995, p. 143). Os relógios extrapolam, conquanto sejam ferramentas de mensuração, uma dimensão puramente utilitarista: a de contar as horas. O narrador observa nos relógios uma relação matemática e cronométrica, embora sua origem seja cosmológica. Não podemos esquecer que esta relação é a inicial, uma vez que é evocado, no parágrafo, Anaximandro de Mileto e seu relógio solar, sciothericon, ancestral e primevo. Os problemas de Anaximandro eram basicamente cosmológicos. O tema cosmológico é reiterado em passagem posterior da linha, quando referido o livro de companhia de J. H., não um manual de relojoaria, mas um livro de astronomia, de Alfraganus (circa 800 - 870.)

A cosmologia, no fundo, entre os pré-socráticos, andava junto com a teologia e teoria do conhecimento. Karl Popper observa a relevância do pensamento pré-socrático em um ensaio no qual diz que a filosofia e ciência, ao se especializarem, perdem a sedução pois abdicam da busca e "deixam de ver e admirar os enigmas do mundo" (POPPER, 1959, p. 2). As perguntas formuladas pelos contemporâneos de Anaximandro, entre eles seu mentor, Tales, especulavam também a forma da Terra e, até mesmo, anteciparam teorias modernas, como a do tectonismo terrestre. De qualquer sorte, havia, para os representantes da escola jônica, algo fundado na noção de estabilidade. A escola de Mileto especulou o mundo como se uma casa.

Havia movimento, havia mudança na casa, havia calor e frio, fogo e umidade: a casa era exposta aos ventos, e um pouco seca, sem dúvida; mas era casa, e isso quer dizer, de algum modo, segurança e estabilidade. Para Heráclito, contudo, a casa estava pegando fogo. (POPPER, 1959, p. 11)

O foco do narrador, contudo, não é cosmológico, mas cosmogônico. Osman Lins foi enfático, em entrevistas,

Teoria, Crítica Literária, outras Artes e Mídias 
em dizer que a proposta de Avalovara assentava-se em cosmogonia:

A construção desta obra é uma construção que nos remete ao cosmos, eu queria realizar um troço que desse uma ideia da ordem cósmica, e é por isso que está lá a história do relógio de Julius Heckethorn, um relógio que representa, na sua minúcia, o cosmos. E todo o romance é construído minuciosamente para remeter à ordem cósmica. (LINS, 1979, p. 223).

O relógio de J.H. representa não um mecanismo com fins de mensuração mas, simulta neamente espécie de obra de arte e joia, de criação: "situa-se no centro de uma teia de relações mais complexa e a mbígua que a existente em torno de um relógio de Sol ou da que justifica os relógios astronômicos." (LINS, 1995, p. 275). Podemos afirmar: o centro da teia é a própria construção poética do livro, de rigor em que se assenta, do cálculo que, em uma harmonia de imponderáveis, é invadido pela incalculabilidade da vida e seus imprevistos, avessa à pla nificação estrita. Avalovara mostra-se a si, revelando paulatinamente os segredos aos que leem suas páginas ta mbém como prova do infinito e da vida que sustêm sua leitura Desenhando uma história que, no painel do(s) presente(s) que pinta (o tempo dos verbos da narração do romance inteiro é o presente do indicativo), retrocede para uma história antiga (de 200 a.C) - a narrativa da linha S, que é uma linha que explica metalinguisticamente a estrutura do livro, fala de um escravo que, tentando conquistar sua liberdade, decide por tirar a própria vida ao perceber que, uma frase a ele revelada em sonho "SATOR AREPO TENET OPERA ROTAS”, sua chance de libertação, tornou-se conhecida por todos e vulgarizada nas ruas - mas ta mbém aponta um caminho de liberdade para o protagonista, Abel, que escreve no Brasil da ditadura militar dos anos 70 e, pela escrita, tenta se contrapor à opressão. $O$ protagonista e sua a mante são assassinados. (A morte da cena final de Avalovara, contudo, representa a libertação que possibilita o caminho para o Paraíso.)

O relógio de J.H, mesmo sendo fruto de tanta engenhosidade, não desperta atenção à primeira vista:

[N]o mais, é um relógio como os outros e só um pouco mais alto, em seu gênero, que a média. Entretanto, soam as horas (um número incôngruo de notas) e então passamos a vê-lo com olhos novos: os sons, diversos dos que ouvimos em geral, surpreendem-nos. Cresce nossa estranheza ao percebermos que não se repetem, antes variam nas horas seguintes, sem que possamos alcançar a lei - pois há de haver um - que rege tais mudanças. Conhecidos os princípios que orientam o fabrico do relógio, serão também explicadas essa lei e uma parcela 
de suas implicações. Acrescentará nosso interesse por um engenho assim raro, a narrativa de certas vicissitudes humanas com ele relacionadas. (LINS, 1995, p. 175).

É chamado de máquina e a designação talvez reforce sua constituição íntima, minuciosa e mecânica. (Ressoa o eco da tradição camoniana da máquina do mundo). Da aparência em nada inconfundível, surge-lhe um segredo musical: toca, à medida que marca as horas, melodias que não se repetem. A máquina é regida por uma lei (secreta?) que deve de haver: as relações estruturais de sua construção. A complexidade mecânica e física é sobrepujada pelo componente musical, secreta mente engendrado em seu bojo e meticulosamente programado por J. H. (O.L.?) O comum da aparência dá lugar ao incomum sonoro que se revela em surpresa. De puras artes mecânicas, J.H se interessa cada vez mais, enqua nto progride em seu treina mento musical, pela delicada arte dos relojoeiros. "Julius abre um novo campo de interesse, a arte da relojoaria” (LINS, 1995, p. 241). Seu pai, devido à falência de um negócio de carrilhões e por conta do adultério da esposa, decide se matar. Julius se apaixona por uma alemã chamada Heidi Lampl que, com problemas de visão, aos poucos, torna-se cega. "O casamento realiza-se em janeiro de 1930, sem pompa e um tanto às pressas, a fim de que a noiva, então com vinte anos, possa ainda captar visões da cerimônia: envolve-a, rapidamente, a cegueira total." (LINS, 1995, p. 273). J.H. retorna à sua cidade natal e:

Dedica-se então a projetar e construir o relógio que, de maneira ainda vaga, imagina. A intenção inicial de Julius é basear-se num relógio de azeite ou numa clepsidra. Os relógios correntes, que funcionam a saltos e com os quais estamos habituados, parecem-lhe corromper uma noção que os primeiros instrumentos de medir o tempo, como a ampulheta ou o relógio de sol, restauram e transmitem de um modo menos infiel: a de ser o tempo um fluxo, um fenômeno contínuo e indiviso Muito reflete sobre isto e sobre o quase impossível equilíbrio de processos modernos e de elementos arcaicos que exige para a futura invenção. (LINS, 1995, p. 274.)

A Julius, instiga-lhe a impossibilidade de manter a noção antiga do tempo ser um fluxo contínuo. Decide então pelo mecanismo do relógio a saltos, aos modos de Gerberto de Aquitânia, excluindo a água ou azeite como princípio motor. No fragmento $\mathrm{P6}$, tem-se uma narração que ressalta a própria teoria (ou poética?) sobre o tempo dos relógios e o tempo de Avalovara. Há algo que pulsa e salta na vida humana mesmo havendo-se esquecido o sentido ritual das horas: 
O tempo, flua ou não, repudia as interrupções, os seccionamentos. Contesta-se, no entanto, a tendência do homem a imprimir-lhe um ritmo? Este ritmo surge - é conquistado - com o relógio a saltos. A saltos move-se no corpo o sangue, a saltos atuam os pulmões, move-nos a saltos, mesmo as aves de mais tranqüilo vôo a saltos se deslocam, nadam os peixes movendo, a saltos, as barbatanas, dia e noite são saltos, ir e vir, passar e ressurgir, sim e sim, não e não, e a própria consciência que temos de existir não é contínua, toma-nos e foge, vez por outra assalta-nos, a saltos. Um erro a mbicionarmos, para a representação do tempo, engenhos contínuos, nunca interrompidos, sem pausas, renegando a nossa natureza, que pulsa como pulsam os pulsos - e que tudo corta, como corta o pensamento, em palavras, em sílabas, em letras. Acentua ainda sua decisão: a presença, no mecanismo do relógio a saltos, do cabelo e das molas, corações metálicos da engrenagem, peças em espiral e, a seu modo, figurações palpáveis do tempo, tão claras qual se fossem, da palavra tempo, a representação ideográfica. (LINS, 1995, p. 281). (grifo meu).

A passagem dos saltos, em $\mathrm{P} 6$, se conecta coerente e coesamente ao plano geral da obra. A construção de Avalovara é regida pela relação de uma espiral que, limitada por um quadrado, "(...) o recinto, o âmbito do romance, de que a espiral é a força motriz" (LINS, 1995, p. 18) ascende e "salta" entre as intrigas desenvolvidas no livro. É curiosa sua escolha: "Nem a eternidade basta ria para chegarmos ao término da espiral - ou sequer ao seu princípio. A espiral não tem começo nem fim” (LINS, 1995, p. 16).

Isto nos leva a inquirir a razão pela qual - e o pressuposto é o da intencionalidade -, Osman Lins decidiu utilizar a espiral como força motriz para construir seu romance (não a água ou azeite, mas o cabelo e a mola, objetos espiralados, como o fez Julius Heckethorn para montar seu relógio). Interrompamos o relato da linha P para falar de uma carta que O.L. mandou, durante a escritura do romance, para sua a miga, a professora e crítica literária Leyla Perrone-Moisés. Meses após a implantação do AI-5 pela ditadura militar, em fevereiro de 1969. Na carta dizia das barbaridades do Brasil para a correspondente que estava na França:

Tenho de dar-lhe algumas novidades políticas. Estão matando criancinhas, por medo de que surja, entre elas, um civil. Os cartórios só estão registrando crianças militares e os padres têm ordem para só batizar recém-nascidos com patentes de cabo para cima. Vários generais, mesmo assim, foram mortos com veneno para gafanhoto. O mesmo veneno utilizado no Egito, durante uma das sete pragas. Vários ex-deputados estão aparecendo depois da meia-noite, correndo bicho. Viraram 
lobisomem. A Constituição vai ser datilografada. Cassaram o mandato. O Sermão do Mandato. Consta que o Brasil vai ser governado por uma trilogia. A Arena mudou de nome. Agora é Poema: Partido da Obediência ao Exército, à Marinha e à Aeronáutica. Compraram um abajur para a Câmara dos Vereadores. (apud PERRONE-MOISÉS, 2014, p. 180).

Junto com o relato sobre o Brasil, dizia-lhe dos seus projetos literários:

E depois, e depois........ lá começará o trabalho com o romance que há vários anos trago na cabeça. O romance em espiral. Escute, pelo a mor de Deus, se você, por acaso (EU DISSE POR ACASO, NÃO É PARA PROCURAR, CADA MINUTO AÍ VALE UMA EXISTÊNCIA), encontrar um livro que se chama The curves of life (quem é o autor, meu Deus, vou ver se me lembro), roube-o. Tem uma excelente documentação fotográfica, revelando a presença em caramujos e outros orga nismos marinhos, chifres de caprídeos, ovídeos e antílopes, de espiral na qual Goethe via o símbolo matemático da vida e da evolução; (...) quero dizer, da vida e da evolução espiritual. Não, não me lembro do nome do autor, mas se você pegar um volume de Esthetique des proportions dans la Nature et dans les Arts, de Mathyla C. Ghyka, saberá. Ponto. (apud PERRONEMOISÉS, 2014, p. 181).
A ideia de escrever um romance ligado à espiral perseguia Osman Lins há anos. O autor, esquecido na carta, era o britânico Theodore Andrea Cook. O livro, junto com o de Matila Ghyka, serviu a Lins como um manual repleto de informações e iconografias apresentando a presença da espiral nas "curvas da vida". O próprio empenho de Cook, no seu livro de mais de 500 páginas, fabricou-se após um incidente em que um colega biólogo, de vívida imaginação, relacionou uma concha à coluna de uma escadaria (COOKE, 1914, p. 36). A espiral representa o tempo, no romance, tanto quanto o quadrado, o espaço. Funda-se uma teoria própria que rege a escritura do romance e referida constantemente, por meio de pistas, nas páginas de Avalovara. Faço uma paráfrase da lista elencada por Elizabeth Hazin sobre a aparição das formas de espiral em "A espiral e a página: criação e intertextualidade em Osman Lins” (2013, p. 78), ensaio em que a autora constata a obsessão de Lins pelos motivos alquímicos e geométricos, que constituíram sua poética desde uma pesquisa autenticamente original (em contraponto à tese sustentada, à época, de que Osman Lins seria um nouveau romancier à brasileira, tendo emprestado à ideia de Avalovara a literatos franceses): as escadas de Cha mbord, os pespontos do soutien, as conchas colocadas sobre um cadáver, o disco de Festo, o giro do velocípede, o voo do pássaro Avalovara (que dá nome ao romance), 
os arrondissements da cidade de Paris e os chifres dos diversos animais que perambulam o texto do livro são formas transfiguradas da geometria infinita da espiral...

Voltemos a Julius e seu relógio.

$\mathrm{O}$ artista-relojoeiro pensa em qual deveria ser a forma que animará seu relógio. Anula a possibilidade de relógios de praça ou de igreja, uma vez que os habitantes das cidades (estamos falando do capitalismo reificador do século XX) não mais contemplam tais mecanismos. Sendo um amador, ta mbém desconsidera a feitura de um relógio astronômico ou musical de grandes proporções. A grandeza dos símbolos ligados ao tempo está se perdendo. "Por outro lado, ele sabe: os costumes mudaram. As cidades já não precisam de relógios para os seus habitantes e o sentido como que sacral das horas (hálito do tempo?) perdeu-se para os homens" (LINS, 1995, p. 281). A tecnologia irrompe e os gestos e ritos se esvaem

As informações relacionadas com o sentido rítmico do tempo também caíram em desuso e agora o rádio assume a função dos campanários, informando a esmo a passagem das horas, em cutiladas e não em obediência a um rito. A ideia original, então, é construir um objeto mais ou menos portátil, uma acordina de parede. Os primeiros desenhos convencem-no de que terá maiores possibilidades de cumprir o projeto se dispuser de mais espaço. Um relógio de caixa, eis a medida ideal. A linhagem a que se filia a sua criação, bem o vimos, não é a dos relógios monumentais; nem é a dos relógios graciosos. Dir-se-á ao menos que Julius Heckethorn, com o seu relógio, inscreve-se de modo indiscutível entre os relojoeiros? Com maior força de justiça poderá ser incluído entre os intérpretes ou contempladores do universo. Por sinal, nos meses em que desenha o mecanismo, o livro que traz sempre consigo não é o Arte de Reloxes ou a Memória sobre o Centro de Oscilação do Pêndulo, de Jean Bernovilli de Basiléia, e sim, numa edição holandesa, o Manual de Astronomia Árabe, de Alfraganus. (LINS, 1995, p. 282.)

Sendo o projeto de Julius o de um relógio de parede, em P7, tem-se a mira do fabrico do pêndulo que o constituirá. "Ao pêndulo, cujo desenho faz lembrar um cistro ou um alaúde, consagra extremos cuidados" (LINS, 1995, p. 290). O relógio é comparado a um pássaro, dócil, em uma gaiola envidraçada. A delicadeza e a paciência são os instrumentos do artista, talvez necessá rias para conquistar tal domesticação. Em P8, fala-se do sistema sonoro a rquitetado por J.H., que tocará a introdução da sonata em fá menor (K 462), de Scarlatti. "Distribuir esses grupos de notas de tal modo que se percam uns dos outros dentro do relógio, soem separados e só de tempos em 
tempos voltem a reunir-se - constituindo essa reunião um evento pleno de intenções -, eis o objetivo de Julius." (LINS, 1995, p. 299). A grande questão do relógio é que, ao tocar os fragmentos da melodia, interpõem-se silêncio nunca se sabendo quando a frase de Scarlatti será novamente ouvida na íntegra. O relógio e sua música são a prova da incapacidade da previsão sobre os instantes da vida humana. A própria imponderabilidade dos destinos.

Aduzir que não se destina a invenção de Julius, como em tantos relógios, a anunciar as horas, parece-nos ocioso. Vê-se claramente o que pretende, criar um símbolo da ordem astral. Não, por certo, à maneira de Jean-Baptiste Schwilgué, construtor do último relógio de Estrasburgo, com o seu mecanismo de equações solares e lunares, agulhas indicadoras do Sol e da Lua, esfera celeste, mostrador do tempo aparente e anel do tempo civil. Julius quer evocar as conjunções do cosmos, mas poeticamente; não apenas a móbil ordem celeste, mas a harmonia de imponderáveis que permite a um homem encontrar a mulher com quem se funde, que faz nascer uma obra de arte, uma cidade, um reino.

Cremos, se ignoramos seus segredos, escutar a voz do caos ante o relógio desse contemplador. (LINS, 1995, p. 301) (grifo meu).
O relógio é um símbolo de cuja poesia se evoca o cosmos. O sistema imprevisível de sua melodia reforça a ideia de uma contemplação assombrada perante o desconhecido. "Ta mbém é isso visado por Julius: colocar as pessoas, frente aos sistemas de som do seu relógio, na mesma atitude de perplexidade que se sofre perante o Universo." (LINS, 1995, p. 301). O relógio, objeto embebido da força simbólica intentada por Lins, serve como alegoria do próprio romance. O relógio de J.H. (e o romance de O.L.) assentam-se sob "um esquema rigoroso" (LINS, 1995, p. 301), tal como a ordem que sustém o mundo cósmico. À ordem junta-se também o caos. "Como introduzir, então, na obra, o princípio de imprevisto e de alea tório, inerente à vida?” (LINS, 1995, p. 301).

Em P9, apa recem explicitamente os temas históricos da Segunda Guerra Mundial. "A fabricação das peças, iniciada em 1933, poucos meses após a subida de Hitler ao poder, dura quatro a nos e oito meses." (LINS, 1995, p. 312). Heckethorn é forçado a mudar sua oficina para produzir materiais de guerra. Percebe a trama bélica que se forma e vê na figura do ditador "um homem cujos chifres crescem para dentro e que destrói o mundo à medida que essas raízes furam-lhe os miolos, a travessam a garganta, escavam o coração e esgalham-se." (LINS, 1995, p. 312). O inventor pensa em destruir sua criação. 
"O relógio está pronto, mas ele não se dispõe a acioná-lo. Questões vitais o obsedam. Em sua ânsia de abranger a totalidade das coisas, não terá voltado às costas ao fato particular? Não será ele próprio um erro na máquina? Que máquina? A Máquina da História? Deve pôr em movimento a sua invenção?" (LINS, 1995, p. 312). Julius, com sua mulher, migra para Holanda. O fragmento termina com a referência ao anexo da Áustria. Do plano macroscópico da Europa em guerra, tem-se, também, domesticamente, as dificuldades enfrentadas por Julius, que decide vender seu relógio ao embaixador sueco e retomar, como discípulo de uma professora, os estudos musica is. Julius recebe o convite de integrar um quinteto de câmara, mas não completa sua atividade: a mulher Heidi, é morta em bombardeio e ele, fuzilado como traidor. Os nazistas invadem seus aposentos e encontram seus papéis de criação, incinerando-os.

O relógio deixa de pertencer ao embaixador sueco e é vendido para a esposa de um diplomata brasileiro. A esposa esquece o relógio em um porão. Para o Brasil, quis trazer apenas

(...)os cristais, as baixelas de prata, um sari, bolas de gude (às vezes, sozinha, diverte-se horas inteiras, jogando com elas sobre os grandes tapetes da Embaixada, alguns dos quais utiliza para proteger as coisas transportadas), e jarros chineses da época azul, uma fotografia da rainha com dedicatória, o diadema oferecido por um velho a migo do Nepal, remédios para enjôo e trinta e oito pares de sapa tos. O relógio de Julius fica no porão, esquecido com outras alfaias. (LINS, 1995, p. 325).

O relógio esquecido, não sendo um item que cha masse atenção, perde-se em um porão. A guerra acaba. A vida segue e o diplomata, em 1953, perde sua esposa. "Viúvo, o embaixador, nostálgico de uma Europa que não mais existe e incapaz de readaptar-se ao seu país, vende em leilão os seus trastes e viaja, para não mais voltar, esperando encontrar a migos que morreram ou que nem sequer se lembram dele ou da embaixatriz." (LINS, 1995, p. 326).

O fragmento final (P10) se encerra em uma espécie de solidão que sujeita o relógio a um ostracismo. Ostracismo que dissimula a memória e os mecanismos secretos inventados por seu criador repleto de engenho:

Agora, aí está o relógio, há doze a nos e meio aí está, ante tapetes sem vida e poltronas fanadas, elegante e sóbrio, soando de tempos em tempos, com os seus misteriosos sons. Já ninguém acredita que os aparelhos sonoros, se é que existe mesmo mais de um, reconstituam a frase de Scarlatti. Nem sequer ocorre (a 
quem ocorreria?) que as engrenagens ajustadas e expostas à falha calculada, voluntária, do mecanismo imperfeito, marcham calmamente para esse milagre: a confluência, o eclipse. Julius, perdido no pó, ouvirá esse momento? (LINS, 1995, p. 326).

\section{AVALOVARA E OUTROS CAMINHOS: POETICA PARA} APORÉTICA. TRANSFIGURAÇÕES TEMPORAIS

A linha P, de Avalovara, tem estreita ligação com uma representação do que se faça alegoria do tempo. Tempo, termo tão polissêmico quanto a leitura que se lhe dedicou, por séculos, assunto. Em Avalovara, de modo geral, há vários tratamentos dados ao tempo, cujo tema perpassa outras linhas narrativas. $\mathrm{O}$ ensaio que escreve o protagonista de Avalovara, na linha R, é um texto que, ao gosto a utorreferente e em mise en abyime de Osman Lins, fala do "tempo mítico e das suas relações com a narrativa". (LINS, 1995, p. 157). Na linha P, contudo, a construção do relógio de Julius Heckethorn representa algo distinto, uma alegoria da própria arte de tecer romances...ou fabricar relógios. O tempo, por meio do relógio, é representado, na linha $\mathrm{P}$, como um fundamento da construção roma nesca, que orga niza o caos. A obra é um mundo, um cosmos: o romance, o relógio...
A crítica já destacou - Osman Lins disse-o em diversas entrevistas - como, desde Nove, novena, de 1966, a preocupação poética do escritor pernambuca no se configura progressivamente em termos de uma profunda reflexão criativa em torno da escritura como problema composicional e, ao mesmo tempo, problema político. Poética é, para Osman Lins, Política. A narrativa se entende como cosmogonia (essa é uma das chaves de Avalovara), e, no entanto, surge não de uma origem divina ou autocausada, mas humana, de fabrico intencional, engendrado por uma técnica e por um repertório singular de um artista, nunca alheios à história ou às circunstâncias sociais.

O tempo, ta mpouco alheio à História, é tema predileto de poetas, filósofos e cientistas. (Dos romancistas, é o que se pretende, enfaticamente, neste ensaio anotar.) Seu enigma atravessa a cultura, inquietando e provocando o pensamento humano, entre o antigo e o novo, quase que eliminando tal oposição. Há um consórcio de saberes e interpretações que forma $\mathrm{m}$ um grande manancial de especulações sobre o tempo:

Assim sendo, as antigas reflexões sobre os modos de viver o tempo, de pensá-lo ou de medi-lo, conservam também uma certa validade: Einstein não elimina Newton, os filósofos contemporâneos não eliminam Kant, Hume, São Tomás, Santo 
Agostinho ou Aristóteles. Mal se tenta descrever o tempo do universo visível, tal como ele se oferece à percepção, aos sentidos que não utilizam nenhum instrumento e não conhecem ou não esquecem a sua existência, descobre-se a pertinência das descrições aristotélicas (...), assim como se descobre a profundidade das a nálises agostinianas quando se procura descrever o tempo da vida psíquica tal como aparece à introspecção; Husserl tinha plenamente razão ao afirmar que 'ainda hoje quem quer que se ocupe do problema do tempo deve estudar a fundo os capítulos 14-28 do XI livro das Confessiones (POMIAN, 1993, p.71).

Curiosamente, é, passando por Aristóteles, desde o texto indefinível de Agostinho - nem totalmente poeta, nem totalmente filósofo - , estra nhamente entre a autobiografia e a inquirição teológica, que surge a reflexão mais famosa sobre o tempo ("quid est ergo tempus?"). A base da inquirição é ontológica. Uma das questões esboçadas por Agostinho é a qualidade interior do tempo. Daí que sua concepção funda uma teoria psicológica do tempo, prescindindo da extensão como critério definidor. Como se em uma espécie de introspeção para perceber do tempo as qualidades interiores, Agostinho argumenta que o tempo resulta de uma distensão anímica. Paul Ricoeur menciona que a a nálise agostinia na do tempo oferece um caráter alta mente interroga tivo e até aporético, que nenhuma das teorias antigas do tempo, de Platão a Plotino, leva a tal grau de acuidade. Não somente Agostinho (como Aristóteles) procede sempre a partir de aporias recebidas da tradição, mas a resolução de cada aporia dá lugar a novas dificuldades que não cessam de levar a investigação sempre mais adiante. (RICOEUR, 2010, p. 14.).

Ricoeur, ao trazer Agostinho e Aristóteles para o debate jamais resolvido, seja pela metafísica ou fenomenologia, discorre sobre a capacidade e do poder da narrativa literária de refigurar o tempo. Em Tempo e Narrativa, diz-se: "Será uma tese permanente deste livro que a especulação sobre o tempo é uma ruminação inconclusiva, à qual só replica a atividade narrativa. Não que esta resolva, por substituição, as aporias. Se as resolve, é num sentido poético e não teorético do termo." (RICOEUR, 1994, p. 21).

Podemos, paralela mente a Ricoeur, afirmar que Lins pretendeu transfigurar, via romance, o tempo. Parece um preceito relativa mente bem aceito: o poético, com frequência, antecipa o teórico. Ou mesmo: o poético pressupõe o teórico. Fica a sugestão da leitura do último romance de Osman Lins, A Rainha dos Cárceres da Grécia, onde se diz: "Toda obra de arte configura 
sua própria teoria.” (LINS, 2005, p. 67). Sabe-se que os artistas, não necessariamente teorizando em manuais, teorizam por meio das suas obras. Proust dissera não saber absolutamente nada da teoria de Einstein, apesar de o admirá-lo:

Gostaria muito de falar de Einstein com você! Por mais que você me escreva que eu derivo dele, ou ele de mim, não entendo uma palavra de suas teorias, dado que não sei álgebra. E duvido que ele tenha lido meus romances. Temos, parece, uma maneira análoga de deformar o Tempo. Não posso me dar conta disso, porque se trata de mim mesmo. E não nos conhecemos, além do que ele é um grande cientista (PROUST apud WILLEMART, 2019, 92-93).

Proust e Einstein deformaram o tempo. Osman Lins transforma o tempo, transfigura-o. Nisso, como Ricoeur disse, a literatura não resolve a aporia filosófica do debate metafísico, mas o situa em termos mais manejáveis. O relógio da abertura do romance é pista cifrada que se atualiza durante o romance. São inúmeras vezes que relógios aparecem ao longo da narrativa, numa espécie de museologia indicial daquele artefato.

Artefato, aliás, é uma palavra que bem traduz o papel de que se ocupa o trabalho poético de Osman Lins.
Voltemos à pergunta: por que um relógio é descrito, solitário, em meio à penumbra de uma sala? Ensaiemos a resposta: para anunciar uma das grandes forças que invade, ressoa - como o relógio de Julius Heckethorn - e repercute na estrutura e temática de Avalovara.

Embora não tenha me valido de tal leitura, cabe, ainda, uma lembrança.

É sabido que Osman Lins leu Mircea Eliade, a quem tomou emprestado uma das epígrafes de Avalovara. O.L. estudou com afinco a questão do eterno retorno discutida em um dos mais célebres livros de Eliade, com base em diversas religiões. O.L. interpretou, a seu modo, a noção de cosmogonia e apocalipse. Avalovara é uma espécie de apocalipse. Isso o disse Osman Lins. "Em Avalovara, por exemplo, dei uma visão apocalíptica de São Paulo." (LINS, 1979, p.194). Arrisco dizer que, contudo, não há messianismo nem função soteriológica em Avalovara, ainda que possa ressoar um intertexto bíblico no romance. A salvação não ocorre pela religião e o apocalipse do romance, suas revelações (como da linha R) são pistas para o literário, que não salva, mas traduz um encontro de significado e sentido. Não há no romance a salvação da alma. Há o encontro de corpos. O texto de Lins se afasta do modelo do novo testamento: infunde-se no

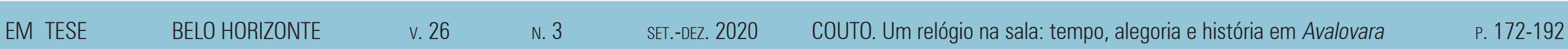

Teoria, Crítica Literária, outras Artes e Mídias 
tantra, no encontro não-binarista de dois ou vários corpos, "em uma não dualidade triunfante". O Gozo, atualizando e amplificando o instante, sugere que o Amor talvez gravite em torno de um centro, podendo este ser a luta política, sem egoísmos e que se enraíza em nossa História. Podendo ser, também, a imaginação ou a Alteridade, que não é descolada da História. Sobre isso a notara Osman Lins, a quem a crítica imedia ta atribuía a pecha de difícil, hermético ou "colonizado":

Eu aceito a história, e me volto para a história, aceito os meus compromissos diante da história e não quero renunciar a eles, principalmente levanto em conta o momento histórico em que nós vivemos no Brasil, um momento que se diz sério, mas é altamente dramático. É possível que se eu vivesse num mundo mais justo, num país mais justo, eu pudesse me entregar de maneira mais tranquila à minha inclinação para uma visão cósmica do homem. No momento, vivo dentro de um conflito, não é porque estou naturalmente voltado para o universo, mas continuo ligado de maneira profunda à realidade do meu tempo, ao dia-a-dia, aos acontecimentos diários do meu povo. É é possível até que isto prejudique os meus escritos, que venha a dar aos meus escritos uma certa carência de unidade. Não faz mal. Eu aceitei esse risco. O que eu não quero é me dissociar dos problemas, do drama do homem brasileiro, do meu povo. (LINS, 1979, p. 219).

\section{NOTAS}

1. "Tudo o que posso fazer é representar o vazamento do tempo mítico no tempo histórico: Ou: a invasão ou vazamento do Todo na parcela." (Nota 8 dos manuscritos prepatón EIRA, 2009, p. 51

2. Listo aqui os trechos do romance que contêm o verbete "relógio" "relógios" com a indicação da letra e número da linha narrativa a que correspondem: "com máos de consertar relogio" O5; "Posso ouvir, marcha do vológio, a serra elétrica e murros numa portada às vozes, " E10; "são dez horas no relógio da estacão da Luz" R21; "nosso reflexo impreciso ante o vidro do relógio" E14: "o relógio o ritmo, a Cidade vôo luz do meio-dia" E16. "exaure "Ee a "o "ato g cresce, entre súplicas e gritos, o compasso do relógio" E16. "o Portador, olha através do pára-brisa cai a chuva um relâmpago olha o relógio de pulso quatro e cinqüenta e cinco" E17: "As engrenagens de som armam-se nas trevas móveis do relógio: faltam quatro minutos para as cinco, estão no ar os dados." E17; "O temido pêndulo relógio dois minutos e meio para as cinco" E17; "armam-se os martelos do relógio o pêndulo um sisto ou alaúde" N2; "canta o relógio e nota após nota flui a melodia fraturada na máquina e conhecemos o que poucos ou ninguém, vivam o que viverem..." N2; "os martelos do relógio ferem precisos as cordas" N2, "falha no relógio o penúltimo grupo da sequência" N2; "falha o penúltimo grupo notas musicais soa o último e o relógio continua a sua busca." N2; "O relógio de São Bento bate meia hora, três pancadas desiguais, que se repetem." O15; "parte do meu salto neste mundo dele irá pender, dele ira pender, como um relógio de algibeira, preso a corrente" 016 "Roos consulta o relogio." (A16); "O relogio de mesa, ladeado por dois viçosos tinhorôes em cachepós de louça, marca onze horas e dez." 018; "O relogio de mesa marca onze horas e catorze minutos." 018 , "lamparina esta acesa no seu copo vermelho e não há relógio no meu quarto. Nem sempre, daqui, ouço o relógio da sala, entre os cachepôs com tinhorões. Não sei que horas são." O18; "sentado junto ao grande relógio de caixa, cujo pêndulo oscila devagar," O20; "Seu relógio barato, de pulso, marca mais ou menos cinco horas." T12; "Olha o relógio: uma e pouco. Tomaria um café."A19; "Gostaria de rever os vitrais e examinar relógio."O22; "Pode-se marcar no relógio o momento em que umo o

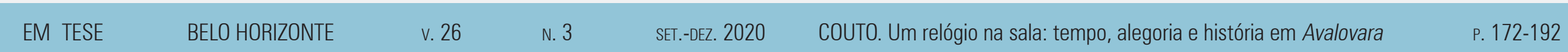

Teoria, Crítica Literária, outras Artes e Mídias 
de briga, batendo-se com outro, começa a entregar-se." T14; "o relógio de Julius Heckethorn" O23; "marcha o relógio de Julius Heckethorn um trovaa a direita, outro a esquerda" 023 ; "Aproveito para olhar relógio: sáo quatro horas e dois minutos. "O23, "Ele voa, o pássaro, da um pás oro cha er." O24; "O Ava cina do relogio, como se fosse óco, sobrevoa um segundo o dorso de Abel e vem pousar no tapete" O24; "Meto o relógio no pulso" T16. “O relógio, no elegante pavihão à entrada, marca quatro menos cinco." A21; “Dez minutos antes (confronto meu relógio com o pequeno e redondo relógio do Pá́cio, no Luxemburgol A21:": "os números amarelos e os ponteiros vermelhos do relógio da entrada em Saint Lazare (por que tantos relógios na estação?)" A21; "O rumor compassado e discreto do relógio ao lado do sofá ressalta ritmo da respiração." E5; "O relógio - desligada a serra mecânica - so a nosso lado e nós nos desprendemos: ouço claramente o carrilhão descontínuo." E6; "Ela pergunta, (...) se as pancadas do relógio na sua incongruência real ou aparente, me dizem alguma coisa." E6; "eu não a reconheço enquanto admito que o magnífico relógio soa de modo bem diverso do que estou habituado a ouvir" E6; "(ressoam ainda as pancadas do relógio)" E6; "(Os coros arcaicos e os versos latinos do long-play, o compasso do relogio, nossas palavras gastas e mesmo assim verdadeiras, beijos mudos, gritos contidos, tilintar das pulseiras nos seus braços.)" E8; "Nossos relógios marcam doze e cinco, hora da sombra maxima." E20. "Para as horas que se acumulam no tempo como hordas, marcadas por uma brutalidade cuja natureza ele ainda não entende com clareza, sao inúteis relógios como este." Pg; "uma oficina para consertos de relogios" Pg; "quando neste produtivo e destrutivo mundo so têm sentido os relógios de ponto e os cronometros de precisão" P10; "tenham imaginado uma tênue peça em forma de espiral, o cabelo, coração do relógios. S9; "caixas de ouro para relogios" A12," "Os relógios, escreve J. H., têm estreita relação com o mundo e o que representam ultrapassa largamente a sua uillade." P1, "Vede os relógios de Sol." P1; "situase no centro de una teia de relaçoes mais complexa e ambigua que a astronômicos." P2 " "uma oficina de para relógios de qualquer espécie" P3; "Os relógios correntes, que funcionam a saltos e com os quais estamos habituados, parecem the corromper uma nocão que os primiros instrumentos de medir o tempo, como a ampulheta ou o relógio de Sol, restauram e transmitem de un modo menos infiel: a de ser o tempo um fluxo, um fenomeno contínuo e indiviso." P5; "Impossível, trabalhando com relógios, manter-se alheio e deixar de obedecer a vozes silenciosas" P5; "Um relógio de caixa, eis a medida ideal. A linhagem a que se filia a sua criaçao, bem o vimos, P6. "As cid relogios monumentais, nem é a dos relógios graciosos." o "As cidan já năo precisam de relógios para os seus habitantes o sentido como que sacral das horas (hálto do tempo?) perdeu-se para partes do mundo, efabricados com instrumentos bem menos precisos, surgem relógios mais engenhosos que o seu." P7; “Aduzir que não se destina a invenção de Julius, como em tantos relógios, a anunciar as

horas, parece-nos ocioso." P8.

\section{REFERÊNCIAS BIBLIOGRÁFICAS}

AGOSTINHO DE HIPONA. Confissões. 2. ed. Tradução de Lorenzo Mammì. São Paulo: Companhia das Letras, 2017.

BORGES, Jorge Luis. Borges oral \& sete noites. Tradução de Heloísa Jahn. São Paulo: Companhia das Letras, 2011

COOK, Theodore Andrea. The Curves of Life: Being an

Account of Spiral Formations and Their Application to Growth in Nature, to Science and to Art; with Special Reference to the Manuscripts of Leonardo Da Vinci. London : Constable, 1914.

DALCASTAGNÈ, Regina. A garganta das coisas: movimentos de Avalovara, de Osman Lins. São Paulo/Brasília: Imprensa Oficial do Estado de São Paulo/Editora da Universidade de Brasília, 2000. 
DOLZANE, Harley Farias \& FERRAZ, Antônio Máximo. Avalovara: Tempo, Ser e Linguagem em ' O Relógio de Julius Heckethorn'. Eutomia, Recife, v. 1, n 13, p. 261 - 282 2014

ELIADE, Mircea. O sagrado e o profano: a essência das religiões. Trad. de Rogério Fernandes. 3. ed. São Paulo: Editora WMF/ Martins Fontes, 2010.

FERREIRA, Ermelinda. Cabeças compostas: a personagem feminina na narrativa de Osman Lins. 2. ed. São Paulo: Edusp, 2005.

HAZIN, Elizabeth. A espiral e a página: criação e intertextualidade em Osman Lins. In: HAZIN, Elizabeth (Org.)O nó dos laços: ensaios sobre Osman Lins. Brasília: Papaterra Editora/ Editora UnB, 2013, p. 69 - 90.

HAZIN, Elizabeth. A ideia insistentemente repetida no velho manuscrito: o colecionamento em Osman Lins. Eutomia, Recife, v. 1, no 13, p. 326-345, 2014.

IGEL, Regina. Osman Lins: uma biografia literária. São Paulo/Brasília: T.A. Queiroz/INL, 1988.
LINS, Osman. A rainha dos cárceres da Grécia. São Paulo: Companhia das Letras, 2005.

LINS, Osman. Avalovara. Apresentação de Antonio Candido 5. ed. São Paulo: Companhia das Letras, 1995.

LINS, Osman. Evangelho na Taba. São Paulo: Summus, 1979

NUNES, Benedito. 0 tempo na narrativa. São Paulo: Edições Loyola, 2013.

PEREIRA, Eder Rodrigues. Da leitura à escritura: matrizes e marginália da estrutura de Avalovara. Manuscrítica, São Paulo, v. 22, p. $159-190,2012$

PEREIRA, Eder Rodrigues. A chave de Jano: os trajetos da criação de Avalovara de Osman Lins. 2009. 309 f.

Dissertação (Mestrado em Teoria Literária e Literatura Comparada) - Faculdade de Filosofia, Letras e Ciências Humanas, Universidade de São Paulo, São Paulo, 2009.

PERRONE-MOISÉS, Leyla. Lembrança de Osman Lins. Eutomia, Recife, v. 1, n. 13, p.177-183, 2014. 
POMIAN, K. Tempo/temporalidade. Enciclopédia Einaudi

Lisboa: Imprensa Nacional/ Casa da Moeda, 1993.

POPPER, Karl R. Back to the Pre-Socratics: The Presidential Address. Proceedings of the Aristotelian Society, Oxford, v. 59, p. 1-24, 1959.

RICOEUR, Paul. Tempo e narrativa (tomo 1). Tradução de Constança Marcondes Cesar. Campinas: Papirus, 1994.

SOARES, Marisa Balthasar. Tempo de Avalovara (as

diferentes dimensões temporais no romance de Osman

Lins) 2007, 168 f. Tese (Doutorado em Letras) - Faculdade de

Filosofia, Letras e Ciências Humanas, Universidade de São

Paulo, São Paulo, 2007

WILLEMART, Philippe Marie. Proust e as ciências.

Manuscrítica, São Paulo, v. 0, n. 38, p. 92 - 94, 2019.

ZÉRAFFA, Michel. La révolution romanesque. Paris: Ed

10/18, 1972 